\begin{tabular}{|l|l|}
\hline Jurnal Bimbingan dan Konseling Pandohop \\
Volume I, Nomor 2, Tahun 202I \\
Tersedia Online: https://e-journal.upr.ac.id/index.php/pdhp \\
e-ISSN 2775-5509
\end{tabular}

\title{
HUBUNGAN ANTARA KESEPIAN DAN KONTROL DIRI DENGAN INTENSITAS BERMAIN GAME ONLINE PADA SISWA DI YOGYAKARTA
}

\author{
Mitta Kurnisari \\ Universitas Negeri Yogyakarta \\ mittakurniasari@uny.ac.id
}

\begin{abstract}
ABSTRAK
Di era yang serba online seperti saat ini, banyak hal dapat dilakukan secara online, salah satunya bermain game online. Kesepian menjadi salah satu alasan seseorang memilih bermain game online untuk mengisi waktu. Kemudahan dalam mengakses semakin mendukung game online memikat banyak kalangan, tak terkecuali siswa. Namun sayangnya kebebasan akses tersebut bisa menjadi sebuah masalah jika siswa tidak memiliki kontrol diri yang baik. Oleh karena itu, penelitian ini bertujuan untuk mengetahui hubungan antara kesepian dan kontrol diri dengan intensitas bermain game online pada siswa. Pendekatan yang digunakan dalam penelitian ini adalah pendekatan kuantitatif dengan jenis penelitian korelasional. Hasil penelitian menunjukkan bahwa ada hubungan positif dan signifikan antara kesepian dengan intensitas bermain game online siswa. Sehingga dapat disimpulkan bahwa semakin tinggi tingkat kesepian individu maka semakin tinggi pula intensitas bermain game onlinenya. Hasil penelitian juga menunjukkan adanya hubungan negatif yang signifikan antara kontrol diri dengan intensitas bermain game online siswa. Artinya, semakin rendah kontrol diri yang dimiliki siswa maka semakin tinggi intensitas bermain game onlinenya.
\end{abstract}

Kata Kunci: kesepian; kontrol diri; game online

\section{THE CORRELATION BETWEEN LONELINESS AND SELF-CONTROL WITH THE INTENSITY OF PLAYING ONLINE GAMES AT STUDENTS}

\begin{abstract}
In an era that is completely online like today, many things can be done online, one of which is playing online games. Loneliness is one of the reasons someone chooses to play online games to pass the time. Ease of access increasingly supports online games attracting many people, including students. But unfortunately the freedom of access can be a problem if students do not have good self-control. Therefore, this study aims to determine the relationship between loneliness and self-control with the intensity of playing online games in students. The approach used in this research is a quantitative approach with the type of correlational research. The results showed that there was a positive and significant relationship between loneliness and the intensity of students playing online games. So it can be concluded that the higher the individual's level of loneliness, the higher the intensity of playing online games. The results also showed that there was a significant negative relationship between self-control and the intensity of students playing online games. That is, the lower the self-control that students have, the higher the intensity of playing online games.
\end{abstract}

Keywords: loneliness; self-controls; game online 


\section{PENDAHULUAN}

Di era globalisasi ini, penggunaan internet pada kalangan pelajar sudah menjadi hal yang wajar dan biasa, bahkan internet itu sendiri kini mulai digunakan oleh anak-anak. Internet semakin berkembang mengikuti perkembangan teknologi yang juga semakin canggih. Komputer sudah bukan hanya milik orang dewasa atau bagi mereka yang bekerja. Anak-anak usia dini pun kini sudah mulai memakai komputer walau hanya untuk sekedar bermain game, sedangkan bagi anak-anak usia sekolah, komputer membantu mereka dalam mengerjakan tugas-tugas sekolah, sehingga pada akhirnya manfaat dan kegunaan buku sebagai sarana membantu siswa mengerjakan tugas pun mulai tersaing oleh canggihnya teknologi yang bernama internet.

Internet merupakan sarana inti dari komputer untuk berkomunikasi. Sistem internet dapat meliput seluruh dunia dan mengandung ribuan koneksi dari jaringan komputer, memberikan sejumlah informasi yang luar biasa banyaknya yang dapat ditelusuri oleh siswa. Dari paparan tersebut nampak bagaimana internet memiliki peran penting dalam perkembangan teknologi informasi yang semakin modern. Internet dapat memberikan informasi terbaru dan terkini lebih cepat daripada buku. Oleh karena itu internet memungkinkan siswa-siswi modern yang haus informasi menjadi lebih memilih internet daripada buku sebagai tempat memperoleh informasi.Salah satu fasilitas internet yang cukup menyita perhatian remaja dan anak-anak adalah game online. Hadirnya game online membuat remaja dan anak-anak tidak ketinggalan untuk mencobanya. Popularitas game online tidak kalah dengan situs-situs online lain di internet.
Hasil studi Santrock (dalam Lesteri, 2015) menemukan bahwa hampir 50\% siswa menggunakan internet setiap hari. Selain itu Santrock (dalam (Prasetyaningrum, 2012) juga mengungkapkan bahwa di antara siswa berusia 15 hingga 17 tahun, sepertiganya menggunakan internet selama 6 jam per minggu atau lebih, $24 \%$ menggunakan internet selama 3 hingga 5 jam per minggu, dan 20\% menghabiskan 1 jam per minggu atau kurang. Meningkatnya minat terhadap game online semakin terlihat dari semakin beragamnya jenis-jenis game online yang ada.

Fenomena game online di kalangan masyarakat membuat keprihatinan tersendiri bagi orang tua. (Puspita Dewi, 2014) menjelaskan dampak negatif bermain game online. Dampak negatif game online dibagi menjadi dua jenis yaitu secara sosial dan psikis. Secara sosial yaitu para pecandu game online menjadi terisolir dari teman-teman dan lingkungan pergaulan nyata, sedangkan secara psikis yaitu pikiran menjadi terus menerus memikirkan game yang sedang dimainkan. Menjadi cuek, acuh tak acuh, kurang peduli terhadap hal-hal yang terjadi di sekeliling kita. Bahkan melakukan apa pun demi bisa bermain game, seperti berbohong, mencuri uang, apapun akan dilakukan demi game online.

Selain dampak di atas, (Fitri et al., 2018) juga mengungkapkan dampak lain dari game online lain bagi perkembangan remaja yaitu dari aspek emosi dan psikomotor. Dari aspek emosi game online dapat menganggu kondisi emosi remaja. Permainan game online yang menantang dapat mengganggu kestabilan emosi remaja sehingga remaja mudah marah atau terlalu sensitif. Kemudian dari aspek psikomotor, remaja yang terus menerus memainkan game online 
dapat mengalami gangguan kesehatan seperti nyeri pada punggung dan gangguan mata.

Berdasarkan pendapat di atas bagaimanapun juga kehadiran game online menimbulkan pro dan kontra di masyarakat itu sendiri. Dampak negatif dan positif bermain game online memang tergantung bagaimana individu bermain game online. Jika individu memiliki kontrol diri yang baik maka dia dapat membuat batasan bagaimana dia akan bermain game online.

Hal ini sejalan dengan pendapat Chaplin (dalam Intani

\& Ifdil, 2018) yang menjelaskan bahwa kontrol diri yaitu kemampuan untuk menekan atau merintangi impuls-impuls atau tingkah laku impulsif. Kemudian Santrock (dalam (Syaibani et al., 2019) juga mengungkapkan bahwa kontrol diri cukup berpengaruh dalam pembentukan perilaku remaja. Kenakalan remaja juga dapat digambarkan sebagai kegagalan untuk mengembangangkan kontrol diri yang cukup dalam hal tingkah laku.

Setiap individu memiliki kontrol diri yang berbeda, ada yang memiliki kontrol diri yang tinggi dan ada individu yang memiliki kontrol diri yang rendah. Remaja yang mempunyai kontrol diri yang rendah akan cenderung mengalami kesulitan dalam mengatur, membatasi, serta mengarahkan perilakunya. Remaja yang memiliki kontrol diri yang tinggi akan mampu mengatur serta mengarahkan perilakunya ke arah yang positif.

Berdasarkan paparan di atas maka dapat disimpulkan bahwa siswa yang memiliki kontrol diri yang baik dapat mengatur intensitas bermain game online mereka sehingga tidak mendapat dampak negatif bermain game online. Siswa yang tidak memiliki kontrol diri yang baik kemungkinan ia akan mengalami kecanduan bermain game online karena tidak dapat menekan keinginan yang muncul untuk terus bermain game online. Kontrol diri yang rendah ini yang dapat menyebabkan dampak negatif berupa kecanduan bermain game online. Hal ini sesuai dengan penelitian yang dilakukan (Karnadi et al., 2019) yang menunjukkan adanya hubungan antara kontrol diri dengan kecanduan internet.

Selain kontrol diri, kesepian juga menjadi salah satu faktor penyebab siswa memiliki intensitas bermain game online yang tinggi. Hal ini sesuai dengan hasil penelitian yang dilakukan oleh (Prabowo \& Juneman, 2012) bahwa semakin sering remaja bermain game online maka ia akan cenderung mempersepsi diri ditolak oleh teman sebayanya karena diikuti dengan perasaan kesepian. Baron dan Byrne (dalam Retnowati, 2015) menyatakan bahwa kesepian merupakan keadaan emosi dan kognitif yang tidak bahagia yang diakibatkan oleh hasrat akan hubungan akrab namun tidak dapat mencapainya. Sesuai dengan karakteristik perkembangan remaja yaitu menjauh dari keluarga dan mendekat dengan teman sebaya. Para pemain game online dapat melakukan interaksi sehingga membentuk sebuah persahabatan antar pemain. Persahabatan tersebut yang kemudian menggantikan hubungan akrab yang tidak dimiliki pemain dalam kehidupan nyatanya. Hal ini sejalan dengan hasil penelitian Lebho et al (2020) yang menemukan fakta bahwa seseorang bermain game online karena tidak ingin merasa kesepian dan dengan bermain game online dapat memenuhi kebutuhan mereka untuk berafiliasi.

Berdasarkan paparan di atas, maka dapat disimpulkan bahwa kesepian dapat menjadi salah satu faktor penyebab remaja memainkan game online. Para 
pemain game online dapat mengalami perasaaan kesepian karena terlalu lama terisolasi dari lingkungannya. Perasaan kesepian muncul akibat dari tidak dimilikinya hubungan akrab yang diinginkan. Hal ini sesuai dengan salah satu tugas perkembangan remaja yaitu mampu membina hubungan sosial yang baik dengan teman sebaya. Oleh karena itu, seorang remaja yang mengalami kesepian dapat mengganggu pemenuhan tugas perkembangan remaja tersebut. Penelitian-penelitian terdahulu mengenai intensitas bermain game online telah banyak dilakukan antara lain Kurniawati (2010) yang meneliti mengenai hubungan bermain game online terhadap perilaku agresif remaja. Kemudian Shatuti (2012) meneliti mengenai hubungan konformitas dengan intensitas bermain game online pada mahasiswa. Sembiring (2017) melakukan penelitian mengenai hubungan antara game online dengan kompetensi sosial pada remaja. Lalu Rochmah (2011) juga melakukan penelitian yang berjudul pengaruh komunikasi interpersonal dan loneliness terhadap adiksi games online. Terakhir penelitian yang dilakukan (Budhi \& Indrawati, 2017) mengenai hubungan antara kontrol diri dengan kecanduan bermain game online pada remaja.

Penelitian ini merupakan penelitian yang berbeda dari penelitian-penelitian tersebut di atas karena menghubungkan variabel intensitas bermain game online dengan variabel kesepian dan kontrol diri yang belum pernah diteliti sebelumnya. Penelitian ini memberikan kontribusi dalam layanan bimbingan dan konseling terutama dalam layanan pribadi sosial. Hasil dari penelitian ini diharapkan akan membantu guru BK dalam mengembangkan program-program layanan bimbingan dan konseling yang bisa diterapkan kepada individu yang memiliki permasalahan dengan intensitas bermain game online yang tinggi. Juga untuk siswa yang mengalami kesepian dan memiliki kontrol diri yang rendah. Berangkat dari fenomena-fenomena yang sudah dipaparkan di atas, maka peneliti merasa tertarik untuk mengetahui bagaimana "Hubungan antara Kesepian dan Kontrol Diri dengan Intensitas Bermain Game Online pada Siswa Di Yogyakarta."

\section{METODOLOGI}

Penelitian ini menggunakan pendekatan kuantitatif dengan jenis penelitian korelasional. Subjek penelitian berjumlah 198 siswa di Yogyakarta diambil dari populasi, dengan menggunakan teknik sampling stratified proportional random sampling. Pada penelitian ini data yang diambil adalah data mengenai kesepian, kontrol diri dan intensitas bermain game online. Data tersebut diperoleh melalui hasil angket kesepian, kontrol diri dan intensitas bermain game online. Data-data tersebut akan diproses dengan menggunakan teknik analisis regresi. Teknik analisis data yang digunakan adalah analisis data deskriptif kuantitatif dengan menggunakan uji prasyarat analisis, uji hipotesis dan sumbangan efektif.

\section{HASIL DAN PEMBAHASAN}

Analisis data dilakukan setelah data dari subjek terkumpul. Sesuai dengan hipotesis pada penelitian ini yaitu mencari hubungan, maka data yang diperoleh kemudian dilakukan uji persyaratan analisis dan uji hipotesis. Berdasarkan data hipotetik skala kesepian, diperoleh hasil nilai minimum hipotetik sebesar $51 \times 1$ $=51$, nilai maksimal hipotetik sebesar $51 \times 4=204$, mean sebesar $(204+51): 2=127,5$ dan standar deviasi sebesar $(204-51): 6=25,5$. Berikut tabel kategorisasi skala kesepian: 
Tabel I. Kategorisasi Skala Kesepian

\begin{tabular}{ccc}
\hline Kategori & Nilai & Frekuensi \\
\hline Tinggi & $\mathrm{X}>153$ & 0 \\
\hline Sedang & $102<\mathrm{X}<153$ & 57 \\
\hline Rendah & $\mathrm{X}<102$ & 141
\end{tabular}

Data hipotetik skala kontrol diri, diperoleh hasil nilai minimum hipotetik sebesar $38 \times 1=38$, nilai maksimal hipotetik sebesar $38 \times 4=152$, mean sebesar $(152+$ 38) $: 2=95$ dan standar deviasi sebesar $(152-38): 6=$ 19. Berikut tabel kategorisasi skala kontrol diri:

Tabel II. Kategorisasi Skala Kontrol Diri

\begin{tabular}{ccc}
\hline Kategori & Nilai & Frekuensi \\
\hline Tinggi & $\mathrm{X}>114$ & 90 \\
\hline Sedang & $76<\mathrm{X}<114$ & 108 \\
\hline Rendah & $\mathrm{X}<76$ & 0
\end{tabular}

Data hipotetik skala intensitas bermain game online, diperoleh hasil nilai minimum hipotetik sebesar 35 X 1 $=35$, nilai maksimal hipotetik sebesar $35 \times 4=140$, mean sebesar $(140+35): 2=87,5$ dan standar deviasi sebesar $(140-35): 6=17,5$. Berikut tabel kategorisasi skala intensitas bermain game online:

Tabel III. Kategorisasi Skala Intensitas Bermain Game Online

\begin{tabular}{ccc}
\hline Kategori & Nilai & Frekuensi \\
\hline Tinggi & $\mathrm{X}>105$ & 2 \\
\hline Sedang & $70<\mathrm{X}<105$ & 69 \\
\hline Rendah & $\mathrm{X}<70$ & 127 \\
\hline
\end{tabular}

Langkah pertama dalam pengujian hipotesis yaitu dengan mengetahui data penelitian yang telah terkumpul berdistribusi normal (uji normalitas) dan hubungan antara variabel bebas dan variabel terikat bersifat linear (uji linearitas). Nilai variabel kesepian, kontrol diri dan intensitas bermain game online masing-masing menunjukkan 0,740, 0,309 dan 0,350 > 0,05 . Uji linearitas diketahui nilai signifikansi untuk variabel kesepian dengan intensitas bermain game online sebesar 0,301 kemudian untuk variabel kontrol diri dengan intensitas bermain game online sebesar 0,763 , maka dapat disimpulkan bahwa $(p>0,05)$. Oleh karena itu bisa disimpulkan bahwa data penelitian berdistribusi normal dan linear sehingga pengujian hipotesis menggunakan statistik parametrik.

Langkah kedua dalam pengujian hipotesis yaitu dengan mengetahui masing-masing variabel bebas dan terikat saling berhubungan atau tidak dengan menggunakan uji korelasi. Hasil analisis korelasi, didapatkan tingkat signifikansi sebesar $\mathrm{p}(0.000)<0.05$ yang artinya signifikan. Hasil tersebut menunjukkan bahwa masing-masing variabel bebas dengan variabel terikat berhubungan, sehingga hipotesis alternatif dapat diterima.

Hasil penelitian di atas menunjukkan bahwa tidak ada (0\%) siswa yang memiliki kesepian pada kategori tinggi, ada 57 siswa $(28,8 \%)$ pada kategori sedang dan 141 siswa (71,2\%) yang berada pada kategori rendah. Tidak adanya siswa yang memiliki kesepian yang tinggi menunjukkan bahwa siswa di Yogyakarta mampu memenuhi kebutuhan untuk merasakan puas dengan hubungan sosialnya. Siswa juga mampu membangun interaksi sosial yang memuaskan. Hal ini sesuai dengan pendapat Peplau dan Perlman (dalam (Wicaksono \& $\mathrm{NRH}, 2019)$ yang menyatakan bahwa individu yang mengalami kesepian adalah individu yang tidak dapat memenuhi kebutuhannya untuk berhubungan atau berinteraksi dengan orang lain.

Pendapat yang sama juga dijelaskan oleh Karnadi et al (2019) yang menyatakan bahwa faktor kesepian menjadi salah satu penyebab seseorang bermain game online, namun hubungan keduanya dalam 
kategori rendah. Artinya ada faktor lain yang menyebabkan seseorang tertarik bermain game online. Oleh karena itu, selain indikator kesepian, indikator kontrol diri menjadi variabel selanjutnya yang akan dibahas keterkaitannya dalam intensitas seseorang bermain game online.

Mengenai kontrol diri diketahui bahwa terdapat 90 siswa $(45,5 \%)$ yang memiliki kontrol diri pada kategori tinggi, 108 siswa $(54,5 \%)$ pada kategori sedang dan tidak ada (0\%) siswa yang berada pada kategori rendah. Kontrol diri siswa dapat dilihat dari kemampuan mengontrol perilaku, kemampuan mengontrol kognitif dan kemampuan mengontrol keputusan.

Mayoritas kontrol diri siswa yang berada pada kategori sedang sesuai dengan pendapat Khairunnisa (2013) yang mengemukakan bahwa usia dan kematangan merupakan faktor internal kontrol diri, maka hasil penelitian tersebut sesuai karena siswa-siswi di Yogyakarta masih berada pada usia remaja dan belum matang sehingga hanya beberapa siswa yang kontrol dirinya mencapai kategori tinggi. Sebagian besar siswa berada pada kategori kontrol diri yang sedang dan hanya sebagian kecil siswa yang berada pada kategori kontrol diri yang tinggi. Hal ini juga dikarenakan remaja merupakan individu yang labil dan terus mengalami perubahan, sehingga remaja menjadi cenderung emosional, gampang tersinggung, murung dan kadang menangis tanpa alasan yang pasti (Poerwanti \& Widodo dalam Pamukti, 2013)

Selanjutnya hasil penelitian juga menunjukkan bahwa terdapat 2 siswa (1\%) yang intensitas bermain game onlinenya pada kategori tinggi, 69 siswa (34,9\%) pada kategori sedang dan 127 siswa (64,1\%) yang berada pada kategori rendah. Intensitas bermain game online yang rendah dapat dipengaruhi berbagai faktor. Lingkungan sosial yang mendukung dengan tidak banyaknya pemain game online di antara siswa-siswi di suatu lingkungan membuat popularitas game online tidak terlalu tinggi. Selain itu banyaknya pilihan kegiatan ekstrakurikuler di sekolah membuat siswa tidak mempunyai waktu untuk mencoba bermain game online.

Hasil analisis menggunakan teknik analisis regresi ganda terhadap data kesepian dan kontrol diri dengan intensitas bermain game online, didapatkan $F_{\text {hitung }}$ sebesar 31,616 dengan tingkat signifikansi sebesar $p=0,000(p<0.05)$ yang artinya signifikan. Hal ini berarti model regresi dapat dipakai untuk memprediksi intensitas bermain game online. Artinya, kesepian dan kontrol diri secara bersama-sama berpengaruh terhadap intensitas bermain game online. Berdasarkan hasil perhitungan analisis regresi tersebut maka hipotesis alternatif $(\mathrm{Ha})$ yang diajukan dalam penelitian ini dapat diterima yaitu terdapat hubungan antara kesepian dan kontrol diri dengan intensitas bermain game online. Hasil analisis tersebut juga menunjukkan bahwa kesepian dan kontrol diri secara bersama-sama memiliki hubungan yang signifikan dengan intensitas bermain game online.

Hasil uji hipotesis minor pertama menunjukkan bahwa nilai koefisien korelasi antara variabel kesepian dengan intensitas bermain game online menyatakan adanya hubungan $\left(r_{x 1 y}\right)$ sebesar $(0.395)$ dengan nilai signifikan $p(0,000)<0,05$. Hal ini berarti hipotesis alternatif ( $\mathrm{Ha}$ ) yang diajukan dalam penelitian ini dapat diterima yaitu ada hubungan yang positif dan signifikan antara kesepian dengan intensitas bermain game online. Artinya, semakin tinggi kesepian maka 
semakin tinggi pula intensitas bermain game online, begitu juga sebaliknya, semakin rendah kesepian maka semakin rendah pula intensitas bermain game online siswa.

Hasil uji hipotesis minor pertama di atas mendukung pendapat Shatuti (2012) yang menyatakan bahwa salah satu faktor penyebab intensitas bermain game online yang tinggi yaitu emotional coping atau sebagai pengalihan salah satunya adalah dari perasaan kesepian. Prabowo \& Juneman (2012) juga menyebutkan bahwa semakin sering remaja bermain game online maka ia akan cenderung mempersepsi diri ditolak oleh teman sebayanya karena diikuti dengan perasaan kesepian. Sedangkan kesepian merupakan keadaan emosi dan kognitif yang tidak bahagia yang diakibatkan oleh hasrat akan hubungan akrab namun tidak dapat mencapainya (Atmoko, 2020). Oleh karena itu remaja yang mengalami kesepian memainkan game online untuk membangun hubungan akrab yang tidak ia dapatkan dari lingkungan sekitarnya.

Selanjutnya hasil uji hipotesis minor kedua menunjukkan bahwa nilai koefisien korelasi antara variabel kontrol diri dengan intensitas bermain game online menyatakan adanya hubungan $\left(r_{x 2 y}\right)$ sebesar ($0.414)$ dengan nilai signifikan $\mathrm{p}(0,000)<0,05$. Hal ini berarti hipotesis alternatif ( $\mathrm{Ha}$ ) yang diajukan dalam penelitian ini dapat diterima yaitu ada hubungan yang negatif dan signifikan antara kontrol diri dengan intensitas bermain game online. Artinya, semakin rendah kontrol diri maka semakin tinggi intensitas bermain game online, begitu juga sebaliknya, semakin tinggi kontrol diri maka semakin rendah intensitas bermain game online siswa.
Hal ini sesuai dengan hasil penelitian yang dilakukan (Prabowo \& Juneman, 2012) yang menyatakan bahwa ada hubungan negatif antara kontrol diri dengan kecanduan Internet. Kontrol diri cukup berpengaruh dalam pembentukan perilaku remaja (Santrock, 2003). Remaja dengan kontrol diri yang rendah akan cenderung mengalami kesulitan dalam mengatur, membatasi, serta mengarahkan perilakunya. Oleh karena itu intensitas bermain game online yang tinggi dapat disebabkan karena kontrol diri yang rendah. Hal ini sesuai dengan pendapat Chaplin (dalam Intani \& Ifdil, 2018) yang mengemukakan bahwa kontrol diri adalah kemampuan untuk menekan atau merintangi impuls-impuls atau tingkah laku impulsif.

Latif Iskandar (2013) mengemukakan beberapa faktor yang melatarbelakangi seseorang bermain game online yaitu adanya tawaran kebebasan, keberagaman pilihan dan daya tarik elemen-elemen game. Hal ini kemudian menimbulkan keinginan pada para pemain game online untuk terus memainkan game online sehingga akhirnya menimbulkan intensitas bermain game online yang tinggi. Sejalan dengan pendapat tersebut, Budhi \& Indrawati (2017) juga mengemukakan bahwa individu yang mengalami kecanduan game online dipengaruhi oleh kemampuan individu dalam mengontrol dirinya.

Hasil analisis tersebut mendukung penelitianpenelitian sebelumnya yang mengkaitkan intensitas bermain maupun kecanduan game online dengan perilaku agresif (Kurniawati, 2010), konformitas (Shatuti, 2012), kompetensi sosial (Sembiring, 2017) dan yang terakhir komunikasi interpersonal dan loneliness (Rochmah, 2011).

Berdasarkan hasil penelitian di atas, meskipun ditemukan hubungan antara kesepian dan kontrol diri 
dengan intensitas bermain game online pada siswa, namun sumbangan kesepian dan kontrol diri terhadap intensitas bermain game online tidak cukup besar. Hal ini dapat dilihat dari hasil perhitungan bahwa sumbangan variabel kesepian dan kontrol diri dalam intensitas bermain game online sebesar 32,8\%. Dengan demikian masih ada $67,2 \%$ faktor lain yang mempengaruhi intensitas bermain game online siswa.

\section{KESIMPULAN}

Berdasarkan hasil penelitian yang telah diuraikan sebelumnya, maka dapat diambil kesimpulan bahwa terdapat hubungan positif yang signifikan antara kesepian dengan intensitas bermain game online pada siswa di Yogyakarta. Artinya, semakin tinggi kesepian yang dimiliki siswa maka semakin tinggi pula intensitas bermain game online. Kemudian terdapat hubungan negatif yang signifikan antara kontrol diri dengan intensitas bermain game online pada siswa di Yogyakarta Artinya, semakin rendah kontrol diri yang dimiliki siswa maka semakin tinggi intensitas bermain game online nya. Dan terdapat hubungan yang signifikan antara kesepian dan kontrol diri secara bersama-sama dengan intensitas bermain game online pada siswa di Yogyakarta. Saran yang diajukan untuk peneliti selanjutnya yaitu dapat memperhatikan faktor lain selain kesepian dan kontrol diri yang mempengaruhi intensitas bermain game online pada siswa sehingga hasilnya dapat diuji kembali.

\section{REFERENSI}

Atmoko, H. D. (2020). Hubungan Antara Dukungan Sosial Dengan Kesepian Pada Anggota Persit Kartika Chandra Kirana Yang Ditinggal Tugas Suami. Universitas Mercu Buana Yogyakarta.

Budhi, F. H., \& Indrawati, E. S. (2017). Hubungan antara kontrol diri dengan intensitas bermain game online pada mahasiswa pemain game online di game center X Semarang. Jurnal Empati, 5(3), $478-481$.

Fitri, E., Erwinda, L., \& Ifdil, I. (2018). Konsep Adiksi Game Online dan Dampaknya terhadap Masalah Mental Emosional Remaja serta Peran Bimbingan dan Konseling. Jurnal Konseling Dan Pendidikan, 6(3), 211-219.

Intani, C. P., \& Ifdil, I. (2018). Hubungan kontrol diri dengan prestasi belajar siswa. Jurnal EDUCATIO: Jurnal Pendidikan Indonesia, 4(2), 65-70.

Karnadi, H., Zuhdiyah, Z., \& Yudiani, E. (2019). Hubungan Antara Kontrol Diri dengan Kecanduan Internet pada Siswa Kelas XI SMA Negeri 16 Palembang. Jurnal Intelektualita: Keislaman, Sosial Dan Sains, 8(2), 161-170.

Khairunnisa, A. (2013). Hubungan religiusitas dan kontrol diri dengan perilaku seksual pranikah remaja di MAN 1 Samarinda. Psikoborneo: Jurnal Ilmiah Psikologi, 1(3).

Kurniawati, Y. (2010). Hubungan bermain game online terhadap perilaku agresif remaja. PRODI PSIKOLOGI UNIKA SOEGIJAPRANATA.

Latif Iskandar, I. (2013). Membangun game shooteradventure Teh Legend of Cursed Amulet berbasis desktop. Universitas Komputer Indonesia.

Lebho, M. A., Lerik, M. D. C., Wijaya, R. P. C., \& Littik, S. K. A. (2020). Perilaku Kecanduan Game Online Ditinjau dari Kesepian dan Kebutuhan Berafiliasi pada Remaja. Journal of Health and Behavioral Science, 2(3), 202-212.

Lesteri, T. S. (2015). Perubahan perilaku pacaran remaja sekolah menengah pertama negeri 2 Sendawar di Kutai Barat. Mahasiswa Program S1 Sosiatri-Sosiologi, Fakultas IImu Sosial Dan IImu Politik, Universitas Mulawarman.

Pamukti, R. (2013). Kesulitan Mahasiswa Dalam 
Mengerjakan Soal Ujian Semester Akuntansi Manajemen Ditinjau Dari Aspek Kognitif Dan Motivasi Belajar Mahasiswa Program Studi Pendidikan Akuntansi FKIP UMS Angkatan 2010/2011. Universitas Muhammadiyah Surakarta.

Prabowo, O. (n.d.). PENERIMAAN TEMAN SEBAYA, KESEPIAN, DAN KECANDUAN BERMAIN GIM DARING PADA REMAJA.

Prabowo, O., \& Juneman, J. (2012). Penerimaan Teman Sebaya, Kesepian, dan Kecanduan Bermain Gim Daring pada Remaja di Jakarta. MIMBAR: Jurnal Sosial Dan Pembangunan, 28(1), 9-18.

PRASETYANINGRUM, M. A. Y. U. S. (2012). Kebutuhan Remaja Usia SMA di SMA Stella Duce 2 dan SMA Taman Madya Jetis Yogyakarta dalam Mengakses Situs-situs Internet. UAJY.

Puspita Dewi, N. (2014). Hubungan Antara Intensitas Bermain Game Online Dengan Interaksi Sosial Pada Remaja. Universitas Muhammadiyah Surakarta.

Retnowati, Y. (2015). Love Scammer: Komodifikasi Cinta Dan Kesepian Di Dunia Maya. KOMUNIKOLOGI: Jurnal IImiah IImu Komunikasi, 12(2).

Rochmah, S. (2011). pengaruh komunikasi interpersonal dan loneliness terhadap adiksi games online.

Sembiring, F. R. N. (2017). Hubungan antara kompetensi sosial dengan kecanduan game online pada remaja. Universitas Mercu Buana Yogyakarta.

Shatuti, P. (2012). Hubungan konformitas dengan intensitas bermain game online pada mahasiswa. Prodi Psikologi Unika Soegijapranata.
Syaibani, R., Darmayanti, N., \& Hasanuddin, H. (2019). Hubungan Antara Dukungan Teman Sebaya Dan Kontrol Diri Dengan Kenakalan Remaja Sma Swasta Dharmawangsa. PROCEEDING: THE DREAM OF MILLENIAL GENERATION TO GROW, 2(1).

Wicaksono, K. S., \& NRH, F. (2019). HUBUNGAN ANTARA HARGA DIRI DENGAN FEAR OF MISSING OUT PADA MAHASISWA TAHUN PERTAMA FAKULTAS PSIKOLOGI UNIVERSITAS DIPONEGORO. UNDIP. 